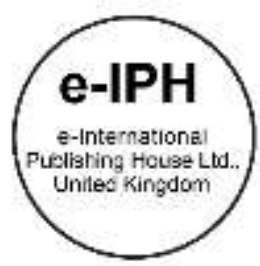

\title{
Negative Impacts of Chalets Operation on the Peninsular Malaysia Marine Park Islands
}

\author{
Zeenat Begam Yusof ${ }^{1}$, Khalilah Zakariya ${ }^{1}$, Roziha Che Haron ${ }^{1}$, \\ Abdul Razak Sapian 1, Nayeem Asif 1, Hayder Jawad Shakir Haraty ${ }^{2}$ \\ ${ }^{1}$ Kulliyyah of Architecture and Environmental Design, International Islamic University Malaysia, \\ 2 Department of Architecture, University of Kufa Iraq
}

zeensoni@iium.edu.my, khalilah@iium.edu.my,roziharon@iium.edu.my, arazaks@iium.edu.my, nayeem@iium.edu.my, hayderharaty@gmail.com Tel: 0193930350

\begin{abstract}
The popularity of marine tourism put intense pressure on the island's environment. Limited studies were conducted to determine the negative impacts caused by chalets operation. Study aim is to investigate the adverse effects caused by the chalet's operation on the Tioman and Perhentian Island. The objectives are to identify operation activities and the negative impact caused by the operation. The study was conducted by adopting qualitative method. The findings indicate solid waste disposal, groundwater extraction, and sewage disposal are destroying the marine environment in many ways. Several recommendations were provided to reduce the negative impacts.
\end{abstract}

Keywords: Chalet operation; Negative impacts; Island environment; Marine tourism

eISSN: 2398-4287@ 2021. The Authors. Published for AMER ABRA cE-Bs by e-International Publishing House, Ltd., UK. This is an open access article under the CC BYNCND license (http://creativecommons.org/licenses/by-nc-nd/4.0/). Peer-review under responsibility of AMER (Association of Malaysian Environment-Behaviour Researchers), ABRA (Association of Behavioural Researchers on Asians/Africans/Arabians) and cE-Bs (Centre for Environment-Behaviour Studies), Faculty of Architecture, Planning \& Surveying, Universiti Teknologi MARA, Malaysia.

DOI: https://doi.org/10.21834/ebpj.v6i18.2953

\subsection{Introduction}

Tourism is one of the leading industries in the world that generates revenues for countries. Tourism flourished due to the natural environment. A healthy natural environment provides good quality of life for tourists. Tourists are more attracted to the natural environment compared to the cities. Many studies agreed that tourism activities imposed positive and negative impacts on the natural environment due to the complex and multifaceted characteristics of the industry (Pramanik \& Ingkadijaya, 2018). Marine tourism is one of the fastest-growing types of tourism (Gedik \& Mugan-Ertugral, 2019). It attracts millions of international tourists worldwide due to its four 'S' slogans such as sun, sand, surf, and sex. Malaysia is one of the 12-mega biodiversity countries in the world. Malaysia has a high level of coral diversities, more than 550 species of corals (Praveena et al. 2012). Malaysia currently has 42 Marine Park Islands (MPIs). The East Coast Peninsular MPIs usually receive high numbers of local and international tourists. Unsustainable operations and overdevelopment of tourism accommodations on the islands create cumulative negative impacts which accelerate deterioration of marine ecological assets (Hamzah \& Hampton, 2013). The popularity of marine tourism put intense pressure on marine ecological assets. Many studies indicate that negative impacts of marine tourism activities are loss of corals ecosystem, seawater pollution, solid waste generation, and loss of marine fish (Wong, 2004, Sadeghian, 2019). However, limited studies were conducted to determine the negative impacts caused by tourism accommodations operation on islands (Benjamin Cowburn et al. 2018). Therefore, it is significant to understand the operation impacts to avoid further degradation of the marine environment. Thus, this study aims to investigate the adverse impacts caused by the chalets operation on the

eISSN: 2398-4287@ 2021. The Authors. Published for AMER ABRA cE-Bs by e-International Publishing House, Ltd., UK. This is an open access article under the CC BYNCND license (http://creativecommons.org/licenses/by-nc-nd/4.0/). Peer-review under responsibility of AMER (Association of Malaysian Environment-Behaviour Researchers), ABRA (Association of Behavioural Researchers on Asians/Africans/Arabians) and cE-Bs (Centre for Environment-Behaviour Studies), Faculty of Architecture, Planning \& Surveying, Universiti Teknologi MARA, Malaysia.

DOI: https://doi.org/10.21834/ebpj.v6i18.2953 
Tioman and Perhentian island. The study's objectives are to identify chalets operation and determine the negative impacts caused by chalets operation on the Tioman and Perhentian marine environment.

\subsection{Literature Review}

Studies of tourism impacts are discussed according to economic, socio-cultural, and environmental dimensions. Many studies have agreed that tourism impacts the dimension positively and negatively (Agarwal et al. 2019). Studies in the early 1970s found that tourism presents positive impacts (Agarwal et al. 2019). The positive impacts are money generation to conserve and preserve historical sites, buildings, and traditional culture. However, studies in the late 1980s and onwards claimed that tourism was causing adverse impacts, especially on the natural environment and socio-culture of the host community (Hall et al. 2016). Studies also mentioned that tourism positively impacts on the economic rather than the socio-cultural and environmental dimensions (Taiminen, 2018). Example of tourism's positive impact on the economic dimension is job employment, infrastructure development, business growth, and revenue generation. An example of tourism's negative impacts the environment and the socio-cultural dimension is the degradation of the natural environment and dilution of the socio-culture of the host community. The negative characteristic of the tourism industry was discussed by McKercher using his 'Fundamental Truths' theory (McKercher, 2005). The 'Fundamental Truths' theory describes the general characteristics of tourism as the ability to over-consume resources, multifaceted and produce waste regardless of any tourism activities. The negative impacts are due to the enormous arrivals of tourists at the destination areas, which causes the mass development of infrastructures such as hotels, roads, airports, restaurants, shops, and entertainment facilities (Agarwal et al. 2019). Moreover, Butler (1980) theory of Tourism Area Life Cycle (TALC) also agreed that tourism destinations have lifecycle stages that eventually come to an end due to the mass development of tourism (Hamzah \& Hampton, 2013). In my opinion, also mass tourism development often destroys the natural environment.

\subsection{Marine tourism impacts}

Marine tourism has been considered one of the fastest-growing forms of tourism in recent decades (Gedik et al. 2019). Negative impacts of marine tourism on the environment are enormous such as ecological loss of corals and marine fish, loss of rare animals and vegetal plants, marine and freshwater pollution, solid waste generation, reduction of natural forest, and fisheries (Huang et al. 2021; Gedik et al. 2019; Abaya et al. 2018; Zhang et al. 2020). Many studies conducted regarding the negative impacts of marine tourism. Analysis of Table 1 indicates most of the studies were conducted to determine the negative impacts of specific tourism activity. For example, studies have been conducted to identify negative impacts from snorkelling, diving, trampling, and boating activities. Meanwhile, studies on the overall impacts of tourism activities on the island's environment are limited (Yusof Z.B., 2018). Most of the studies were conducted to determine the negative impacts caused by marine tourism recreational activities rather than the negative impacts caused by tourism accommodations operations (Hassanli \& Ashwell, 2020). Therefore, to fill the gap between works of literature, this study was conducted.

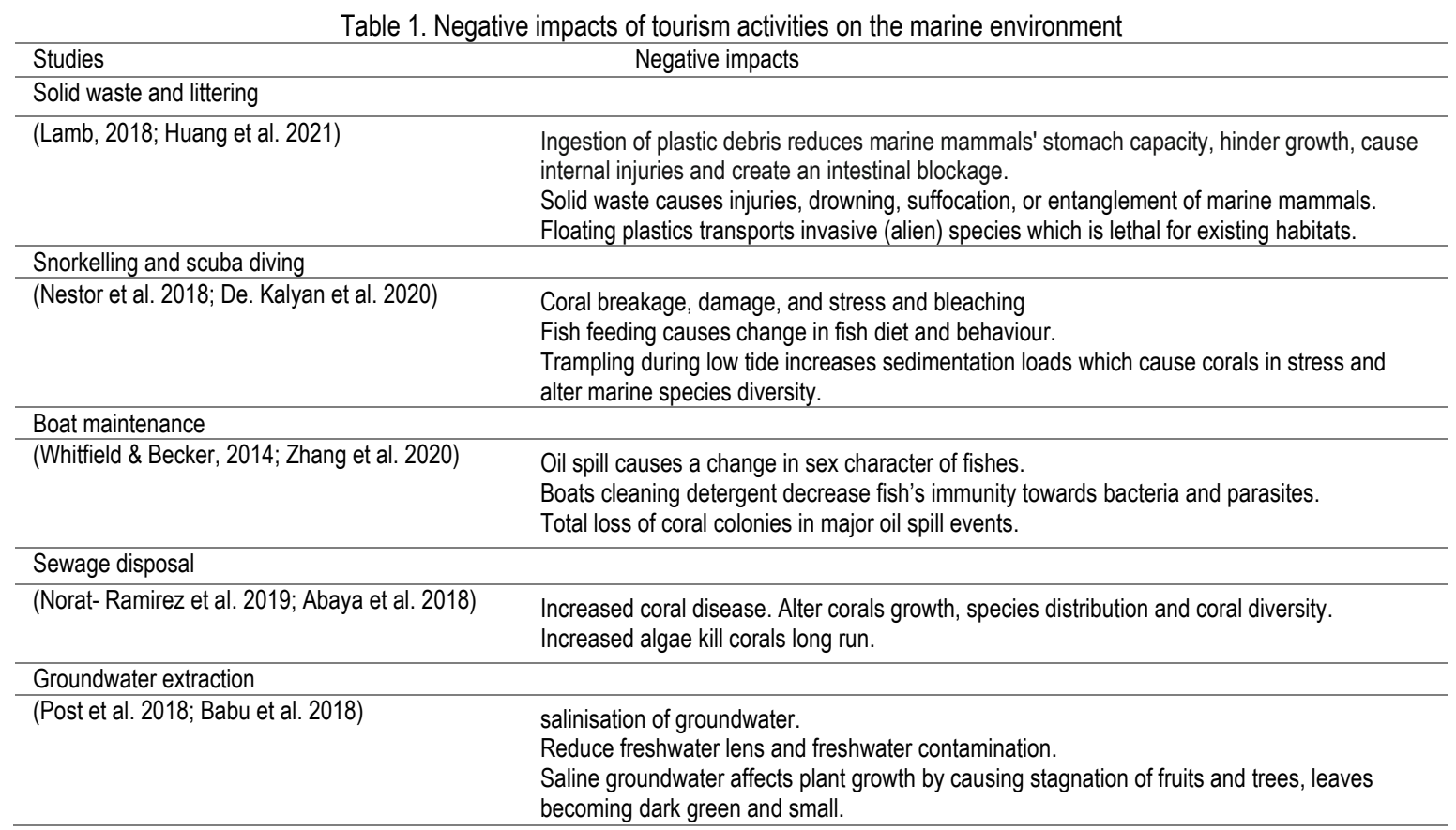

\subsection{Chalets operation}

Tourism accommodations consist of hotels, resorts, motels, chalets, and homestays. This study focuses on chalets because chalets are mushrooming on the MPIs in Malaysia. General characteristics of chalets are heterogeneous in nature, small, limited capital, and owned by a single owner. After aviation and car transport, the tourism accommodation sector is estimated to contribute $21 \%$ of tourism's global greenhouse gas emissions (Hall et al. 2016). The cumulative negative impacts of chalets operation on the environment are substantial 
compared to resorts (Hamzah \& Hampton, 2013). The essential operation of the chalet is front-of-house, back-of-house, and outdoor recreation areas (Yusof Z.B., 2018). Fig. 1 shows the regular operation of the chalet. Mainly all the operation occurs at the back of the house. Operations that have the potential to cause impacts on the natural environment are solid waste, sewage, energy management and freshwater extraction.

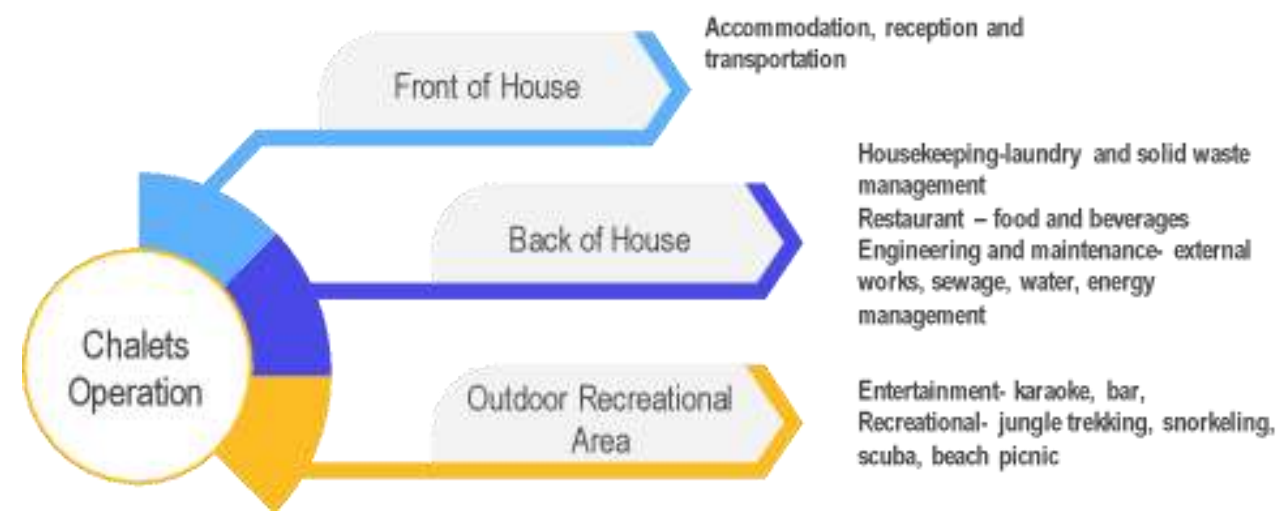

Fig. 1: Chalet spaces and operations

(Source: Author)

\subsection{Methodology}

This study adopted a qualitative research design. Qualitative studies find reality within the subject and collect rich, informative, subjective, holistic, and naturalistic information (Sarantakos, 2005). This study adopts a case studies approach with several techniques such as semistructured interview, structured observation, document analysis and visual method.

\subsection{Case study area}

This study was conducted at the Tioman and Perhentian Island. The islands are located on the East Coast of Peninsular Malaysia. Both islands are known as Marine Park Islands which are rich with marine ecological assets. Both islands have higher numbers of small and medium tourism accommodations which are operating in an unsustainable way according to previous studies. Three chalets were chosen as case studies from each island. The chalets are identified using coding to comply with the data protection agreement.

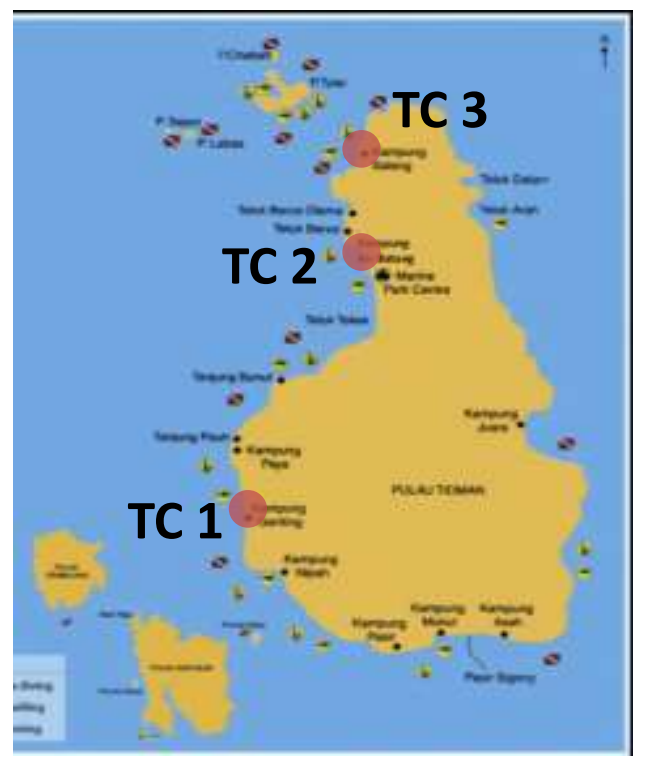

Fig. 2: case studies chalets on Tioman Island (Source: Author)

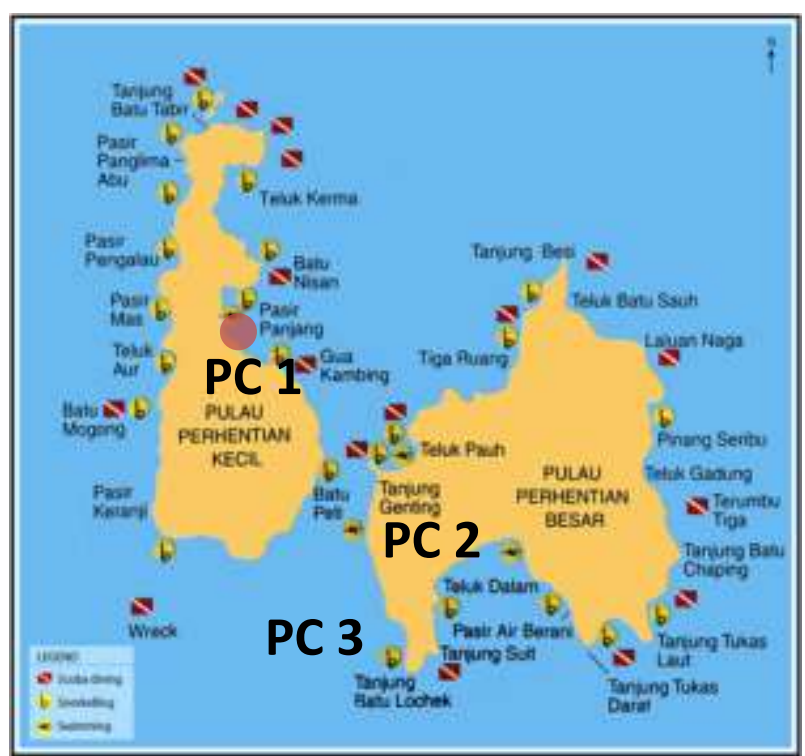

Fig. 3: case studies chalets on Perhentian Islands (Source:Author)

\subsection{Data collection}

This study adopted the semi-structured interview method because it is considered the most appropriate method for qualitative research (Sarantakos, 2005). Six chalet operators were interviewed, and fieldwork was conducted for seven days for each island. The interviews were recorded. The chalets operators were interviewed based on three operation activities: solid waste, freshwater extraction, and sewage 
management. The interview questions are divided into two parts which are operators' background and operation activities. The structured observation was conducted using the checklist method. The checklist was prepared based on the interview questions. The checklist method helps to record on-site information systematically. In addition, videos and photographs were taken and analysed systematically.

\subsection{Findings}

Findings are discussed according to the objectives of the study, which are to identify chalets operation and determine the negative impacts caused by the chalets operation.

\subsection{Background of the chalets}

Tioman Island is the largest MPI in Peninsular Malaysia, with an area of $136 \mathrm{~km}$ square. Tioman Island has nine villages and 75 tourism accommodations. Mostly are chalets, and only nine are resorts (Yusof Z.B, 2018). Where else, Perhentian Island is a small island with an area of $15.35 \mathrm{~km}$ square. Perhentian Island consist of Perhentian Kecil and Perhentian Besar Island. Perhentian Island has 45 tourism accommodations which 30 are chalets. Background information of the chalets on both islands is stated in Table 2. Findings indicate that chalets from both islands started to operate in the late 1980s. Chalets in Tioman Island have a wider land area compared to chalets in Perhentian Island. The findings also indicate that chalets in Tioman and Perhentian have a similar number of units and services.

Table 2. Chalet's background

\begin{tabular}{|c|c|c|c|c|c|c|}
\hline Island & Chalet & area & Year & Units & Location & Tourism services \\
\hline \multirow[t]{3}{*}{$\begin{array}{l}\text { Tioman } \\
\text { Island }\end{array}$} & TC 1 & 3 acres & 1990 & 56 & Kg Genting & $\begin{array}{l}\text { Restaurant, dive centre, rooms, souvenir shop and } \\
\text { laundry }\end{array}$ \\
\hline & TC 2 & 3 acres & 1985 & 30 & Kg Air Batang & $\begin{array}{l}\text { Restaurant, dive centre, laundry, convenient shop, } \\
\text { and water transportation }\end{array}$ \\
\hline & TC 3 & 3 acres & 1988 & 59 & Kg Salang & $\begin{array}{l}\text { Restaurant, dive centre, rooms, laundry, and water } \\
\text { transportation }\end{array}$ \\
\hline \multirow[t]{3}{*}{$\begin{array}{l}\text { Perhentian } \\
\text { island }\end{array}$} & PC 1 & 1.5 acres & 1985 & 69 & $\begin{array}{l}\text { Perhentian } \\
\text { Kecil Island }\end{array}$ & $\begin{array}{l}\text { Restaurant, diving, snorkelling, rooms, laundry, } \\
\text { water transportations }\end{array}$ \\
\hline & PC 2 & 1.8 acres & 1991 & 45 & $\begin{array}{l}\text { Perhentian } \\
\text { Besar Island }\end{array}$ & $\begin{array}{l}\text { Restaurant, diving, snorkelling, rooms, souvenir, } \\
\text { laundry }\end{array}$ \\
\hline & PC 3 & 1.5 acres & 1998 & 65 & $\begin{array}{l}\text { Perhentian } \\
\text { Besar Island }\end{array}$ & $\begin{array}{l}\text { Restaurant, diving, snorkelling, rooms, laundry, } \\
\text { water transportations }\end{array}$ \\
\hline
\end{tabular}

\subsection{Chalets operations}

Analysis of Table 3. indicates that chalets on the same island have similar operation practices. However, there are slight differences in terms of operation between the two islands. The differences are in terms of solid waste disposal and freshwater extraction for both islands. Several villagers appointed by the Tioman Development Authority pick up solid waste on Tioman island and waste transfer to the landfill located at the Tekek village. Meanwhile, waste at the Perhentian Island is collected by a waste contractor appointed by the local authority and disposed of at the Besut mainland. Wastes on both islands are pickup daily. As for freshwater extraction, Tioman operators receive fresh water from streams. Meanwhile, Perhentian operators receive freshwater from ground-driven wells. Freshwater is pumped up continuously from wells using diesel generators. As for sewage management, both islands use a septic tank and soak pits. The number of soak pits is higher compared to septic tanks on the islands. Soak pit is an old type of sewerage system which directly percolate sewage water into the ground. Overflowed sewage water is disposed of at the sea or forest area.

Table 3. Case studies chalets operation

\begin{tabular}{|c|c|c|c|c|c|c|}
\hline \multirow{2}{*}{ Operations } & \multicolumn{3}{|c|}{ Tioman Island } & \multicolumn{3}{|c|}{ Perhentian Island } \\
\hline & TC 1 & TC 2 & TC 3 & PC 1 & PC 2 & PC 3 \\
\hline $\begin{array}{l}\text { Solid waste } \\
\text { management }\end{array}$ & $\begin{array}{l}10 \text { bags of } \\
\text { garbage daily. } \\
\text { Papers and garden } \\
\text { waste burn. No } \\
\text { waste separation. }\end{array}$ & $\begin{array}{l}6 \text { bags of garbage } \\
\text { daily. Garden waste } \\
\text { and papers burn. } \\
\text { Bulky waste buried. } \\
\text { Glass and aluminium } \\
\text { cans recycled. }\end{array}$ & $\begin{array}{l}15 \text { bags of garbage } \\
\text { daily. Garden waste } \\
\text { and papers burn. } \\
\text { Waste separation } \\
\text { and recycling } \\
\text { conducted. }\end{array}$ & $\begin{array}{l}25 \text { bags of garbage } \\
\text { daily. Papers, and } \\
\text { garden waste burnt. } \\
\text { Aluminium cans and } \\
\text { glass bottles recycled. }\end{array}$ & $\begin{array}{l}10 \text { bags of garbage } \\
\text { daily. Papers, and } \\
\text { garden waste burn. } \\
\text { Aluminium cans and } \\
\text { glass bottles recycled. }\end{array}$ & $\begin{array}{l}20-30 \text { bags of garbage } \\
\text { daily. Aluminium cans } \\
\text { and glass bottles } \\
\text { recycled. }\end{array}$ \\
\hline $\begin{array}{l}\text { Freshwater } \\
\text { extraction }\end{array}$ & $\begin{array}{l}\text { Water intake from } \\
\text { stream. Drinking \& } \\
\text { cooking water from } \\
\text { mineral bottles. No } \\
\text { water saving } \\
\text { strategies }\end{array}$ & $\begin{array}{l}\text { Water intake from } \\
\text { stream and } 1 \text { driven } \\
\text { ground well. Stream } \\
\text { water filtered for } \\
\text { cooking and } \\
\text { drinking. No water } \\
\text { saving strategies }\end{array}$ & $\begin{array}{l}\text { Water intake from } \\
\text { stream. Drinking \& } \\
\text { cooking water from } \\
\text { stream water. No } \\
\text { water saving } \\
\text { strategies }\end{array}$ & $\begin{array}{l}\text { Water intake from } 2 \\
\text { ground driven well. } \\
\text { Tap water from village } \\
\text { use for drinking and } \\
\text { cooking. No water } \\
\text { saving strategies }\end{array}$ & $\begin{array}{l}\text { Water intake from } 2 \\
\text { ground driven well. } \\
\text { Tap water for drinking } \\
\text { and cooking. No water } \\
\text { saving strategies }\end{array}$ & $\begin{array}{l}\text { Water intake from } 5 \\
\text { ground driven well. } \\
\text { Tap water for drinking } \\
\text { and cooking. Water } \\
\text { saving strategies } \\
\text { adopted }\end{array}$ \\
\hline $\begin{array}{l}\text { Sewage } \\
\text { disposal and } \\
\text { management }\end{array}$ & $\begin{array}{l}11 \text { septic tanks } \\
\text { and } 12 \text { soak pits. } \\
\text { Overflow sewage } \\
\text { water discharge to } \\
\text { the forest or sea }\end{array}$ & $\begin{array}{l}5 \text { septic tanks and } \\
12 \text { soak pits. } \\
\text { Overflow sewage } \\
\text { water discharged to } \\
\text { the forest. }\end{array}$ & $\begin{array}{l}12 \text { septic tanks and } \\
11 \text { soak pits. } \\
\text { Overflow sewage } \\
\text { water discharged to } \\
\text { the forest or sea. }\end{array}$ & $\begin{array}{l}3 \text { units of septic tanks } \\
\text { and } 15 \text { units of soak } \\
\text { pits. Overflowing } \\
\text { sewage is discharged }\end{array}$ & $\begin{array}{l}4 \text { septic tanks. } \\
\text { Overflowing sewage } \\
\text { sludge is discharged to } \\
\text { the sea or forest area. }\end{array}$ & $\begin{array}{l}5 \text { units of septic tanks } \\
\text { and } 20 \text { units of soak } \\
\text { pits. The sludge is } \\
\text { discharged to the } \\
\text { forest area. }\end{array}$ \\
\hline
\end{tabular}




\subsection{Discussion}

\subsection{Impacts from the solid waste operation on the marine environment}

The main issues of both islands are improper disposal and excessive production of solid waste. High numbers of chalets and tourists produce huge amounts of solid waste on the islands. Improper management of solid waste on the islands are causing adverse impacts on the marine ecological assets (Sadeghian, 2019). Tioman and Perhentian operators collect all wastes at the beach for pickup by the waste contractor. During fieldwork, many garbage bags were seen on PC 1 and PC 2 beaches. According to the PC 2 operator, "storm lasted few days which unable waste contractors to collect garbage for several days from the beach. Consequently, rough waves drag all the piled-up garbage into the sea". Accumulations of garbage in the sea cause ingestion problem, injuries, and entanglement of marine fish and turtles (Arabi, \& Nahman, 2020). The ingestion of plastic can reduce stomach capacity, hinder growth, cause internal injuries, and create an intestinal blockage of marine animals. Moreover, some studies indicate plastics waste can cause coral disease (Lamb et al 2018; Huang et al, 2021)

Meanwhile, garbage left on the beaches for a few days produces leachate water that seeps or flows towards the sea. Leachate water promotes algae and seagrass growth. High amounts of algae kill coral reefs. Leachate waters decrease fish immune systems towards bacterial infections and diseases. Observation indicates slimy green coral patches along the beach, which indicate high growth of algae in front of the PC 2 chalet. Findings also indicate that all the chalets burn their garbage daily. Based on the site observation, all the operators' burned plastic bottles, boxes, and all sorts of waste except PC 3 operator. The burning process produces various dangerous gasses such as furans, dioxins and monoxide gases that contribute to global warming and the acidification of seawater. Acidification of seawater affects the well-being of the coral habitats locally and worldwide. According to TC 3 operator, some operators bury various types of bulky waste in the ground, such as inoperative TVs, air-conditioners and used diesel oils on Tioman Island. The reason is no service allocated by local authorities to pick up bulky waste from the island. Decomposition of the bulky waste contaminates groundwater. Overall findings indicate that Tioman and Perhentian Islands are not clean. A lot of garbage and bulky waste was found on the beaches and in the forest behind the chalets.

\subsection{Impacts from freshwater extraction on the marine environment}

Chalets on Tioman Island receive freshwater from streams. Meanwhile, chalets on Perhentian Island receive freshwater from groundwater. During the field survey, two operating activities were recognised that are causing contamination of groundwater. The activities are excessive extraction of groundwater and the use of soak pit as a sewerage system. Groundwater reserve for small islands is limited. The groundwater scarcity usually occurs on the islands during the dry season, which coincidently is the peak season in Malaysia. During the dry season, groundwater is slightly saline and less in quantity compared to the monsoon season. Over-pumping of groundwater distorts the natural recharge-discharge equilibrium process, which leads to seawater intrusion. Seawater intrusion can cause irreversible deteriorations of groundwater quality in terms of drinking water quality (Gedik et al. 2019; Babu et al. 2018; Post et al. 2018).

Perhentian Island operators agreed that groundwater tasted brackish and not suitable for drinking. Moreover, high salinity concentration in groundwater affects plant growth. Affected plants exhibit several symptoms such as plants growing slowly or stunned, fruits being stunned, and leaves becoming dark green, smaller, and thicker. The PC 3 and PC1 operators mentioned that their fruits and herbs trees are not growing well on the islands, and most of the trees near the beach take a long time to grow. Excessive use of soak pits also contaminates groundwater with E-coli bacteria, nitrate, and phosphate.

\subsection{Impacts from sewage management on the marine environment}

Tioman and Perhentian Island have the highest number of tourist accommodations compared to the other MPIs. Sewage pollution has been identified as one of the main issues on both islands. The reasons identified are that many operators use inefficient sewage systems and empty untreated sewage water directly into the sea or stream. Findings indicate that the use of soak pits is highest on both islands. $A$ soak pit system is a poor sewage management system. Soak pits easily clog and overload with the sewage water. Consequently, operators need to empty the pits frequently. According to the TC 2 and TC 3, they channelled overflow soak pit water into the sea and forest. Sewage water caused high algae proliferation. High amounts of algae can take over coral reefs and eventually kill the whole colony. Moreover, untreated sewage water percolates into the ground causing groundwater pollution (Gedik et al. 2019). Untreated sewage water contains organic matters, E. Coli bacteria, nitrate and phosphate from detergents, which deteriorate the quality of the groundwater and seawater (Sadeghian, 2019). According to Rahman, Noor, Saad, \& Yunus (2015) a study indicate a high level of nitrate and phosphate in Tioman chalets groundwater wells near the beach. During observation, TC 2 and PC 1 operators discharge their kitchen, laundry, and toilet water directly to the nearby stream that flows to the sea. Most of the streams observed on the Tioman and Perhentian Island are very polluted. Moreover, the PC 2 operator said that "the resort beside mine is so crowded, and when you walk by, you can smell sewage and sea algae at the beach". Reef Check Malaysia 2020 report also indicated that the algae level is high at all beaches of Perhentian Island. All the findings above indicate that Tioman and Perhentian island groundwater and seawater are highly polluted with sewage. 


\subsection{Conclusion and Recommendations}

This study was conducted in a short time due to the limitation of budget and time. Other limitations are this study focuses on the onsite impacts rather than longitudinal impacts. Only six chalets operators agreed for this study from 20 operators approached. This study indicates that chalets on both islands have similar operation practices in freshwater, solid waste, and sewage management. The majority of the operators are not conducting green operation practices which leads to detrimental impacts on the island's marine ecological assets. Improper disposal and excessive production of solid waste affect the well-being of corals and marine fish. The excessive amount of garbage on the islands is due to high numbers of tourist arrivals, far from the mainland, small capacity of waste boats, and unpredictable weather conditions. Some recommendations for solid waste management are waste separation, recycling, reuse, limitation of mineral water bottles, and limitation of plastic food packaging. In addition, the local authority should hire bigger waste boats for pickup. Continuous freshwater extraction from streams and groundwater is causing seawater intrusion into groundwater, deterioration of groundwater quality, and affects plants growth. Some recommendations for water saving practices are water-saving closets, showerheads, and taps, rainwater harvesting, limited pumping of groundwater during the dry season, and greywater channelling to plant beds. The soak pit system and discharging overflow sewage water into the sea are causing negative impacts such as seawater pollution with E. coli bacteria, groundwater pollution, algae proliferation, corals bleaching, coral smothering, and bacterial infection of marine fishes. Some recommendations for sewage management are efficient septic tanks, separation of black and greywater, use of eco-friendly detergents, annual maintenance of septic tanks, sludge composting, and an environmental awareness program for operators. This study can be continued using similar method for a bigger scale to identify cumulative negative impacts caused by tourism accommodations on other Malaysian MPIs.

\section{Acknowledgments}

This research grant fund by MOHE under the FRGS RACER 2019-1 Grant (RACER/1/2019/SSI11/UIAM/11)

\section{Paper contribution to related field of study}

This study has contributed knowledge in tourism impacts on marine environment and hospitality industry

\section{References}

Abaya, L. M., Wiegner, T. N., Beets, J. P., Colbert, S. L., Kaile'a, M. C., \& Kramer, K. L. (2018). Spatial distribution of sewage pollution on a Hawaiian coral reef. Marine pollution bulletin, 130, 335-347.

Agarwal, R., Kariyapol, T., \& Pienchob, N. (2019). Positive and negative impacts of tourism on environment: A case study of Pattaya City, Thailand. Sripatum Review of Humanities and Social Sciences, 19(1), 136-147.

Arabi, S., \& Nahman, A. (2020). Impacts of marine plastic on ecosystem services and economy: State of South African research. South African Journal of Science, 116(56), $1-7$.

Babu, R., Park, N., Yoon, S., \& Kula, T. (2018). Sharp Interface Approach for Regional and Well Scale Modelling of Small Island Freshwater Lens: Tongatapu Island. Water, 10(11), 1636.

Cheng Li, T. (2013, October 1). Pulau Perhentian Reefs under attack from algae. The Star Online. Retrieved from https:/l www.thestar.com.my/news/environment30/01/01/pulau-perhentian-reefs-under-attack-from-algae/

Cowburn, B., Moritz, C., Birrell, C., Grimsditch, G., \& Abdulla, A. (2018). Can luxury and environmental sustainability co-exist? Assessing the environmental impact of resort tourism on coral reefs in the Maldives. Ocean \& coastal management, 158, 120-127.

De, Kalyan., Nanajkar, M., Mote, S., \& Ingole, B. (2020). Coral damage by recreational diving activities in a Marine Protected Area of India: Unaccountability leading to 'tragedy of the not so commons'. Marine Pollution Bulletin, 155, 111190

Gedik, S., \& Mugan-Ertugral, S. (2019). The effects of marine tourism on water pollution. Fresenius Environ. Bull, 28, 863-866.

Hall, C. M., Dayal, N., Majstorovic, D., Mills, H., Paul-Andrews, L., Wallace, C., \& Truong, V. D. (2016). Accommodation consumers and providers' attitudes, behaviours and practices for sustainability: A systematic review. Sustainability, 8(7).

Hamzah, A., \& Hampton, M. P. (2013). Resilience and non-linear change in island tourism. Tourism Geographies, 15(1), $43-67$.

Hassanli, N., \& Ashwell, J. (2020). The contribution of small accommodations to a sustainable tourism industry. Current Issues in Tourism, 23(3), 261-264.

Huang, W., Chen, M., Song, B., Deng, J., Shen, M., Chen, Q., \& Liang, J. (2021). Microplastics in the coral reefs and their potential impacts on corals: A mini-review. Science of The Total Environment, 762,143112

Lamb, Joleah B., Bette L. Willis, Evan A. Fiorenza, Courtney S. Couch, Robert Howard, Douglas N. Rader, James D. True et al. "Plastic waste associated with disease on coral reefs." Science 359, no. 6374 (2018): 460-462.

Malaysia, R. C. (2020). Status of coral reefs in Malaysia, 2015. Reef check Malaysia survey report, Reef Check Malaysia.

McKercher, B. (2005). Destinations as products? A reflection on butler's life cycle. Tourism Recreation Research, 30(3), 97-102. 
Nestor, V., Otto, E. I., Gouezo, M., Marino, L., Mereb, G., Olsudong, D., \& Golbuu, Y. (2018). Impact of snorkelers on shallow coral reefs in the Rock Island Southern Lagoon.

Norat-Ramírez, J., Méndez-Lázaro, P., Hernández-Delgado, E. A., Mattei-Torres, H., \& Cordero-Rivera, L. (2019). A septic waste index model to measure the impact of septic tanks on coastal water quality and coral reef communities in Rincon, Puerto Rico. Ocean \& Coastal Management, 169, 201-213.

Praveena, S. M., Siraj, S. S., \& Aris, A. Z. (2012). Coral reefs studies and threats in Malaysia: a mini review. Reviews in Environmental Science and Bio/Technology, 11(1) 27-39.

Pramanik, P. D., \& Ingkadijaya, R. (2018, April). The impact of tourism on village society and its environmental. In IOP Conference Series: Earth and Environmental Science (Vol. 145, No. 1, p. 012060). IOP Publishing.

Post, V. E., Bosserelle, A. L., Galvis, S. C., Sinclair, P. J., \& Werner, A. D. (2018). On the resilience of small-island freshwater lenses: Evidence of the long-term impacts of groundwater abstraction on Bonriki Island, Kiribati. Journal of hydrology, 564, 133-148.

Rahman, M. M., Noor, N. M., Saad, S., \& Yunus, K. (2016). Coastal water quality of Tioman Island: Effects of human activity and the distance from shoreline. Desalination and Water Treatment, 57 (1), 83-87

Sadeghian, M. M. (2019). Negative environmental impacts of tourism, a brief review. J. Nov. Appl. Sci, 8, 71-76.

Sarantakos, S. (2005). Social research (3rd Ed). New York: Palgrave Macmillan

Taiminen, S. (2018). The negative impacts of over tourism on tourism destination from environmental and socio-cultural perspectives.

Teik Hoong, T. (2005). RM60 mil project to rehabilitate Tioman. Star Online. Retrievedhttp://www.thestar.com.my/story/?file=/2005/3/29/nation/10486003\&sec=nation

Wong, P. P. (2004). Environmental impacts of tourism. A companion to tourism, 450-461.

Yusof, Z. B. (2018). Green Operation Practices for MSIC operators at the East Coast Peninsular Malaysia Marine Park Islands. (Doctoral Thesis, Universiti Teknologi Mara, Malaysia.

Zhang, T., Wang, D., Liu, R., Xie, Y., Li, J., \& Wang, L. (2020). A coral reef-like structure fabricated on cellulose paper for simultaneous oil-water separation and electromagnetic shielding protection. ACS omega, 5(29), 18105-18113 